\title{
Algorithm of Competition Intensity Assessment for a Local Market
}

\author{
Fedulova I.Yu.* \\ Voronezh State Agrarian University named after Emperor \\ Peter the Great \\ Voronezh, Russia \\ E-mail: irinaf-2010@mail.ru
}

\author{
Shevtsova N.M. \\ Voronezh State Agrarian University named after Emperor \\ Peter the Great \\ Voronezh, Russia \\ E-mail: shevtsova_nm@mail.ru
}

\author{
Sabetova T.V. \\ Voronezh State Agrarian University named after Emperor \\ Peter the Great \\ Voronezh, Russia \\ E-mail: tsabetova@mail.ru \\ Zakshevskaya E.V. \\ Voronezh State Agrarian University named after Emperor \\ Peter the Great \\ Voronezh, Russia \\ E-mail: elenazak@inbox.ru
}

\begin{abstract}
Competitiveness improvement is currently one of the urgent problems of the development of Russian economy sector. Methods and procedures for the qualitative assessment of competitiveness of agro-industrial companies are becoming especially important. The competition level is crucial for the development of the market. Features of competition in economy sector are determined by the specifics of this sector. Assessment of the competition level allows adequate adjusting of the strategy of a company. In order to analyze the competition level in the local market, the authors propose the use of the analysis of the size of the market share of participants, the concentration index and the Herfindahl-Hirschman index, for markets with a large number of producers, the coefficient of variation can be used in construction. The obtained quantitative analytical indicators more informatively characterize the market situation, which allows finding, implementing and monitoring the effectiveness of management decisions in various areas.
\end{abstract}

Keywords - development, competitiveness, local market, Herfindahl-Hirschman index, market.

\section{INTRODUCTION}

The term "economic competition" comes from the Latin word "concurrere" (which means "to collide", "compete") and means struggle or rivalry in some field, aimed at getting some advantages in case of victory. The development of market relations is impossible without competition, which is one of the main elements of the organizational and economic mechanism of market development $[1,2,3]$. Competitiveness is a multi-level concept and includes the competitiveness of both the company and the product, as well as intellectual property that are involved in the economic turnover.

The relevance and importance of the theoretical and practical aspects of company competitiveness for the majority of economic entities determines the constant interest in this area of both foreign and domestic researchers [4-8]. However, very insufficient attention is paid to the sectoral specificity of business entities, which significantly affects the essence of competitiveness and its regulatory tools.
Uncertainties and risks that are inevitable in a market economy require the disclosure of environmental factors, their impact on the internal conditions of functioning and market stability of companies. Competition in the market system requires the use of a targeted approach in management. Market research, product evaluation according to competitiveness criteria allow business entities to use different competitive strategies and concentrate on individual market segments. In this regard, the study of competition in the agricultural sector, the definition of criteria, indicators, factors and systems for ensuring the competitiveness of products and business-units is a very relevant scientific field.

A necessary condition for obtaining dominant competitive position in the market is the formation of an effective business development strategy in the regional management system, which will ensure the production of the right products and their timely sale, increase entrepreneurial profitability and consumer satisfaction. At the same time, an adequate understanding of the current economic situation in a particular product market, the competitive positions of its main participants and ways to increase their competitiveness are necessary.

\section{LITERATURE REVIEW}

The assessment of the level of competition allows adjusting and optimizing the competitive strategy for a particular company operating in the market [9-19].

In fact, any product in the market is tested for the degree of satisfaction of the existing public needs. Each buyer purchases exactly the product that most fully meets his personal needs. Therefore, the competitiveness of a product can be determined only by comparing the products of competitors with each other. In other words, one can say that competitiveness is a relative concept, clearly tied to the market and moment of sale. Product competitiveness is a combination of quality and cost characteristics of a product that ensures the satisfaction of a specific customer need. 
Although competitiveness is an internal property of an economic entity and exists regardless of its practical implementation, the need for its development, as well as assessment, grows precisely as competition intensifies.

The term "competitiveness" is widely used both in the scientific and educational literature in economics, and by the general public. However, despite this and the close attention of academicians to this issue, a single universally recognized definition of this category has not yet been worked out.

It should be emphasized that there is no consensus even on the relationship between competition and competitiveness. Thus, there is an opinion that competitiveness not only finds its practical expression under the conditions of competition, but also ceases to exist in its absence [21]. This circumstance is attributed to the complexity of the interpretation of this concept, its dependence on the concept of "competition", as well as on its types and strength of influence on the activities of economic entities.

The authors of this work consider it necessary to point out that competitiveness is objectively inherent in a wide variety of entities that can, in principle, be compared under certain conditions, and does not disappear in the absence of competition (for example, in a monopolistic market), although it cannot be practically realized in this situation, turning into a kind of sleeping state. Moreover, based on the analysis of academic literature in various disciplines, it was concluded that competitiveness is not a purely economic category. For example, the competitiveness of individuals is possible both in the labor market and in other areas and for benefits other than employment, wages, and working conditions.

Nevertheless, one cannot but recognizes the interdependence of research and assessments of competition and competitiveness. The level of company competitiveness depends on many factors that can conditionally be grouped into two blocks: competitive environment and allocation. The nature and essence of the influence of factors of the competitive environment can be represented as a model of the five forces of competition. The result of the impact of this block of factors is the corresponding strategic positioning of the company, which adequacy degree to the existing competitive balance is directly related to the level of competitiveness of the company in question.

\section{MATERIALS AND METHODS}

In order to assess the competitive environment of the market of agricultural products in the Gribanovsky district of the Voronezh region, conditional administrative boundaries were adopted. In general, it can be noted that the accuracy requirements for measuring boundaries are characterized by a significant degree of approximation and a number of conventions

The level of competition is understood as the percentage of the influence of companies of the same sector on the development of the entire business through the pursuit of their own leadership $[14,15]$.

In our study we used:
- analysis of the market share size for each participant and the proportion of them [16];

- concentration index;

- Herfindahl-Hirschman index [17, 18].

Based on the analysis of theoretical studies on the essence of company competitiveness, its refined definition was proposed: company competitiveness is a socio-economic category, which allows judging about the extent to which a company is able to produce products, to the maximum extent satisfying existing or potential demand in terms of price and quality; the ability of the company to resist the other manufacturers of similar products in the market and maintain its market niche; to have long-term, strategic advantages over other companies of the given industry, as well as the ability to adapt to changes in the external environment.

\section{RESULTS}

The volume of sales of agricultural products in 2016 among the agricultural companies of the Gribanovsky district was 4218100 ths RUR, and in 2017 it decreased to just 4115 848 ths RUR. Sales of agricultural products are represented with several goods, mostly produced by crop farming (Table 1).

TABLE I. STRUCTURE OF AGRICULTURAL PRODUCT SALES IN THE GRIBANOVSKY DISTRICT IN TERMS OF GOODS IN 2016-2017

\begin{tabular}{|l|l|l|l|l|l|l|}
\hline \multicolumn{1}{|c|}{ Goods } & \multicolumn{2}{|c|}{$\begin{array}{c}\text { Number of } \\
\text { sellers }\end{array}$} & \multicolumn{2}{c|}{$\begin{array}{c}\text { Average price, } \\
\text { RUR/c }\end{array}$} & $\begin{array}{l}\text { Share in the sales } \\
\text { structure, \% }\end{array}$ \\
\hline & 2016 & 2017 & 2016 & 2017 & 2016 & 2017 \\
\hline Wheat & 9 & 8 & 723.5 & 496.2 & 15.4 & 21.2 \\
\hline Rye & 1 & - & 245.6 & - & 0.0 & - \\
\hline Millet & 2 & 1 & 620.2 & 448.1 & 0.0 & 0.0 \\
\hline Buckwheat & 2 & 3 & 2563.7 & 1631.5 & 0.1 & 0.1 \\
\hline Corn & 3 & 2 & 828.7 & 720.9 & 6.1 & 4.5 \\
\hline Barley & 7 & 7 & 628.5 & 551.4 & 2.8 & 3.0 \\
\hline Pea & 2 & 2 & 1259.2 & 1596.6 & 0.9 & 0.6 \\
\hline Sunflower & 9 & 8 & 2138.6 & 1662.7 & 21.8 & 15.3 \\
\hline Soy & 4 & 3 & 2478.5 & 1744.7 & 0.8 & 0.6 \\
\hline Sugar beetroot & 6 & 6 & 313.6 & 216.3 & 44.5 & 26.3 \\
\hline Crop farming in total & 9 & 8 & $\mathrm{X}$ & $\mathrm{X}$ & 92.6 & 71.8 \\
\hline Live weight of cows & 1 & 1 & 8279.7 & 8152.0 & 0.0 & 0.1 \\
\hline $\begin{array}{l}\text { Live weight of sheep } \\
\text { and goats }\end{array}$ & 2 & 1 & 8404.9 & 13084.5 & 0.0 & 0.1 \\
\hline Milk & 1 & 1 & 2399.9 & 2676.0 & 0.3 & 0.5 \\
\hline $\begin{array}{l}\text { Animal husbandry in } \\
\text { total }\end{array}$ & 2 & 2 & $\mathrm{X}$ & $\mathrm{X}$ & 0.4 & 0.7 \\
\hline
\end{tabular}

We should note that the largest share of the district total revenue is taken by sugar beetroot $(44.5 \%$ in 2016 and $26.3 \%$ in 2017), while the shares of sunflower $(21.8 \%$ and $15.3 \%$ correspondingly) and wheat (15.4\% and $21.2 \%$ in 2016 and 2017) are considerably smaller.

Among other types of products, corn and barley are of particular interest. The shares of other types of commodity products, including all livestock products, are negligibly small, therefore, in our opinion, there is no sense in considering the intensity of competition in their markets. 
Moreover, all 8-9 farms located in the region compete only in the wheat and sunflower markets, 6 of them in the sugar beet market and 7 in the barley market. The rest of the products are supplied by only 1 to 3 farms in the area.

The key commodity markets of the region are the markets of wheat, corn, barley, soybeans, sunflower and sugar beet. Based on the above, we do not consider it necessary to analyze the markets for other goods.

Consider the participation of different companies of the Gribanovsky district in the markets for those types of products. Table 2 shows the participation of the companies in the sales of certain product types, the key ones for the Gribanovsky district, and their share in the total revenue from the sale of each product.

TABLE II. STRUCTURE OF THE KEY PRODUCT MARKETS IN THE GRIBANOVSKY DISTRICT IN TERMS OF SELLERS IN 2016-2017

\begin{tabular}{|c|c|c|c|c|c|c|}
\hline \multirow[b]{2}{*}{ Company } & \multicolumn{6}{|c|}{ Share in the sales structure, \% } \\
\hline & wheat & corn & barley & sunflower & soy & $\begin{array}{c}\text { sugar } \\
\text { beetroot }\end{array}$ \\
\hline \multicolumn{7}{|c|}{2016} \\
\hline Farm «Liga» & 0.92 & - & 0.29 & 1.37 & - & 1.81 \\
\hline $\begin{array}{l}\text { «ATG Kirsanovsky» } \\
\text { Ltd. }\end{array}$ & 4.90 & - & 19.44 & 4.28 & 13.94 & 4.73 \\
\hline $\begin{array}{l}\text { «Gribanovsky sugar } \\
\text { refinery» Ltd. }\end{array}$ & 77.54 & 30.89 & 70.60 & 76.33 & - & 74.32 \\
\hline $\begin{array}{l}\text { «Dubravnoye-Agro» } \\
\text { Ltd. }\end{array}$ & 2.92 & - & 0.31 & 1.64 & 27.95 & 1.27 \\
\hline $\begin{array}{l}\text { «Novomakarskoe» } \\
\text { Ltd. }\end{array}$ & 1.79 & - & 0.33 & 4.34 & 53.37 & - \\
\hline «Posevkinskoye» Ltd. & 0.69 & - & - & 0.43 & - & - \\
\hline «Region-Agro» Ltd. & 0.12 & - & - & 0.41 & - & - \\
\hline «Russia-Agro» Ltd. & 0.81 & 0.28 & 1.19 & 1.04 & - & 7.99 \\
\hline «Harvest» Ltd. & 10.32 & 68.83 & 7.84 & 10.15 & 4.74 & 9.88 \\
\hline $\begin{array}{l}\text { Total sales revenue, } \\
\text { ths RUR }\end{array}$ & 649915 & 256738 & 117478 & 921625 & 34947 & 1875818 \\
\hline \multicolumn{7}{|c|}{2017} \\
\hline Farm «Liga» & 1.29 & - & 4.66 & 2.57 & - & 2.17 \\
\hline $\begin{array}{l}\text { «ATG Kirsanovsky» } \\
\text { Ltd. }\end{array}$ & 4.98 & - & 19.08 & 3.44 & 22.32 & 6.67 \\
\hline $\begin{array}{l}\text { «Gribanovsky sugar } \\
\text { refinery» Ltd. }\end{array}$ & 81.72 & 68.42 & 55.29 & 71.62 & - & 66.74 \\
\hline $\begin{array}{l}\text { «Dubravnoye-Agro» } \\
\text { Ltd. }\end{array}$ & 1.47 & - & 1.53 & 1.92 & 11.08 & 1.72 \\
\hline «Posevkinskoye» Ltd. & 1.03 & - & - & 0.04 & - & - \\
\hline «Region-Agro» Ltd. & 0.24 & - & 0.40 & 0.33 & - & - \\
\hline «Russia-Agro» Ltd. & 4.43 & - & 6.85 & 0.09 & - & 13.42 \\
\hline «Harvest» Ltd. & 4.85 & 31.58 & 12.19 & 19.99 & 66.6 & 9.29 \\
\hline $\begin{array}{l}\text { Total sales revenue, } \\
\text { ths RUR } \\
\end{array}$ & 873976 & 124739 & 124838 & 630634 & 22939 & 1082157 \\
\hline
\end{tabular}

We drew the following conclusions from the data presented in table 2 :

1. In the markets of all six types of commodity products in the Gribanovsky district, only one company is represented "Harvest" Ltd. The other 4 companies compete with it in five of the six commodity markets under review.

2. The district has the pronounced leader in the production and marketing of crop production, "Gribanovsky Sugar Refinery", which had a share of about $75 \%$ in four out of the six considered markets in 2016, and in 2017 it had the share of over two thirds, but in one market it is not represented at all. At the same time, it is important to note that in the same four commodity markets, "Harvest" Ltd. has the second or third largest shares, although, naturally, it still turns out to be several times smaller than the leader's share.

3. Three out of nine companies (in 2017 - from the remaining eight companies of the district) are negligible in terms of their shares in all reviewed commodity markets; those include Farm "Liga", "Posevkinskoe" Ltd., and "RegionAgro" Ltd. This is due to the very small size of these companies in general.

Thus, without the use of any additional methods for assessing competition, it can be assumed that all the markets in question will be concentrated, even monopolistic.

In the international practice, the dominant firm is such a company that has a market share of $25 \%$ or more. According to Russian law, the dominant firm is a company that has more than $35 \%$ of the market, and judging from some other data even more than $40 \%$. The dominance of a firm in the market can be ensured, for example, by an advantage in production costs.

Speaking of the market of crop products of the Gribanovsky district, we observe that "Gribanovsky Sugar Refinery" Ltd. has the share of over $40 \%$ in the wheat, barley, sunflower, and sugar beet markets, "Novomakarskoe" Ltd. in the soybean market (2016), and "Harvest" Ltd. - in the corn market.

To assess the degree of the market competitiveness, the concentration index $\mathrm{CR}$ is used - this is an indicator characterizing what market share falls on a given number of the largest players. Since the concept of "the given number" seems rather vague, then after the letters CR, a number is added, which shows how many of the largest market players are considered. Thus, in reality, the following $\mathrm{CR}$ concentration indices are mainly used: CR2, CR3, CR4, CR5, CR8, CR10. In our case, we will be referring to the large market participants as the three companies with leading market shares [19].

Then for the wheat market of the Gribanovsky district we calculate the CR3 index using the formula Eq. (1)

$$
C R_{n}=\sum_{i=1}^{n} S_{i},
$$

where $S_{i}$ - market share of $i$-th company, $\% ; n$ - number of companies within "the given number" of the largest players, which for CR3 takes the form:

$$
\mathrm{CR} 3=\mathrm{S}_{1}+\mathrm{S}_{2}+\mathrm{S}_{3} .
$$

In our case we calculate such index for the revenue $(\mathrm{R})$ :

$$
\mathrm{CR} 3_{\mathrm{R}}=4.90+77.54+10.32=92.76 .
$$

Similarly, we calculate $C R 3_{R}=100.0$ in the corn market, since there are only 3 companies here, in the barley market $\mathrm{CR} 3_{\mathrm{R}}=97.88$, in the sunflower market $\mathrm{CR} 3_{\mathrm{R}}=90.82$, in the sugar beet market $C R 3_{R}=92.19$, and in the soybean market $\mathrm{CR} 3_{\mathrm{R}}=95.26$.

The higher is the concentration and monopolization of the market, the closer the concentration index is to 100 (especially the fewer firms at the same time fall into the number of large 
ones). In our case, we observe serious monopolization of the market.

The market concentration Herfindahl-Hirschman index (HHI) is also widely used to assess the market, especially in countries with an Anglo-Saxon economic type, in particular, in the USA, where it is even used as an indicator defining the need to obtain permission for mergers and acquisitions by the antimonopoly service Eq. (2):

$$
H H I=\sum_{i=1}^{n} S_{i}^{2},
$$

where $S_{i}$ - market share of $i$-th company, $\% ; n$ - number of market participants.

Usually three market types in terms of this indicator are considered:

I group - markets of high monopolization (concentration) level (monopolistic markets) $1800<\mathrm{HHI}<10000$;

II group - markets of considerable monopolization (concentration) level (oligopolistic markets) $1000<\mathrm{HHI}<1800$;

III group - markets of low monopolization (concentration) level (competitive markets) HHI $<1000$.

In the studied case for 2 years under consideration the index for various markets was from 3640.6 to 6751.6. The indicators and results are shown in Fig 1 in more detail.

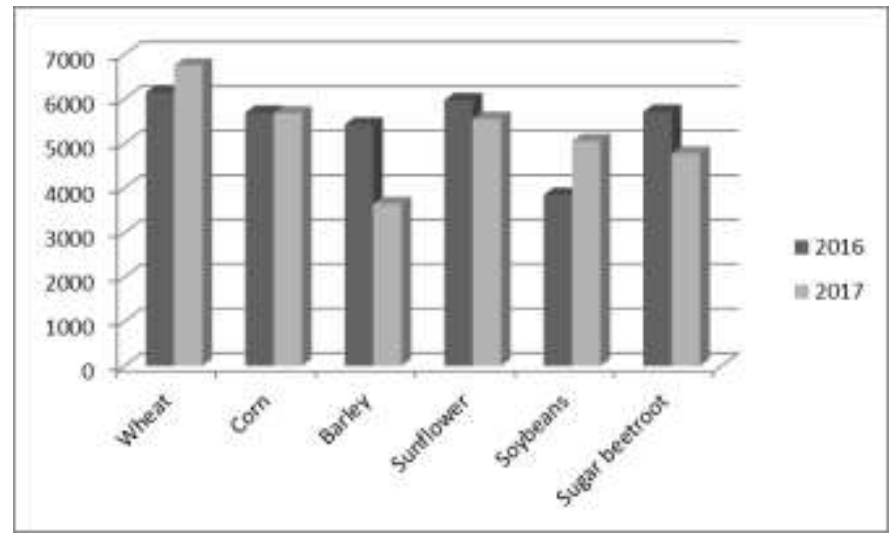

Fig. 1. HHI for the markets of the six crops in Gribanovskiy district in 20162017.

Thus, all six markets belong to markets with high concentration level, that is, to monopolistic ones.

The calculations based on 2017 data are not indicators of significant changes in most markets, which is normal, since the level of competition intensity rarely changes so rapidly. However, over the year, some circumstances have changed in the agribusiness markets of the Gribanovsky district. Firstly, the share of product markets attributable to "Gribanovsky Sugar Refinery" Ltd. in all markets decreased in 2017, except for the wheat and corn market. This contributed to the decrease in the concentration of four product markets. Secondly, in general, only eight companies remained in the Gribanovsky district, which, in turn, made all markets more concentrated. That fact especially affected the markets of those crops where not all the companies of the district are already represented, while the company that left the market was present in four out of six markets. Thus, in general, the wheat and soybean markets became significantly more concentrated in 2017, the corn and sunflower markets maintained approximately the same or slightly lower concentration levels as in 2016, and the concentration in the barley and sugar beetroot markets decreased significantly.

\section{CONCLUSION}

According to the results of the analysis of the competition intensity in the market of the Gribanovsky district, we came to the conclusion that this market is highly concentrated. Consequently, "Gribanovsky Sugar Refinery" Ltd., which is a leader and can even be recognized as a monopolist in most agrarian commodity markets of the district, has a huge advantage in maintaining its leading position. Despite the steady second place of "Harvest" Ltd., it must be admitted that it is difficult to get nearer leadership for this company, and in some segments (for example, in the sugar beet market) it is absolutely impossible. On the other hand, in those segments where the leader is "Harvest" Ltd., it is relatively easy for it and extremely important as well to retain its leading positions. The third and fourth place in most positions are divided by "ATG Kirsanovsky" Ltd. and "Russia-Agro" Ltd., but their lagging behind the leaders is such that the only available strategy for them is to follow the leader in terms of price and quality characteristics of products.

The obtained quantitative analytical indicators more informatively characterize the market situation, which allows finding, implementing and monitoring the effectiveness of management decisions in various areas of agricultural companies:

- justification of sectoral focus, specialization and product policy;

- selection of an optimal market niche and protection of its competitive position;

- search and selection of sales channels;

- $\quad$ pricing and cost policy;

- long-term solutions in the area of production procurement with resources, including both material and technical, as well as personnel, and information.

\section{References}

[1] S.S. Saghravanian, M. Samadi, M.E. Hajiabadi, "Evaluating the market power and coalition formation in double-sided power market: An analytical decomposition approach", Int. J. Of Electr. Power \& Energy Syst., no. 118, art. no. 105766,2020

[2] S. Stanciu, F.O. Virlanuta, O.A. Vochin et al., "Fast Moving Consumer Goods (Fmcg) Market In Romania Features And Trends", Amfiteatru Econ., vol. 21, spec. iss. 13, pp. 778-794, 2019.

[3] T.V. Sarycheva, L.P. Bakumenko, M.N. Shvetsov, "Assessment Of The Competitiveness Of Economic Activities Of The Region In Terms Of Employment", Mediterranean J. Of Soc. Sci., vol. 3, no. 6, pp. 119-126, 2015.

[4] M. Kostić, L. Maksimović, B. Stojanović, "The limitations of competition in the insurance markets of Slovenia, Croatia and Serbia", Econ. Res.-Ekon. Istraživanja, vol. 29 no. 1, pp. 395-418, 2016. 
[5] V.G. Zakshevskiy, I.F. Khitskov, O.G. Charykova et al., Strategic directions for agriculturel development in the Voronezh region. 2017, $212 \mathrm{p}$

[6] M.E. Otinova, Z.V. Gavrilova, Yu.A. Ivakhnenko, "Interaction between the state and agricultural business in the dairy market", FES: Finance. Econ. Strat., no. 12, pp. 53-59, 2017.

[7] Y. Katsoulacos, G. Makri, E. Metsiou, "Antitrust Enforcement in Europe in the Last 25 Years: Developments and Challenges", Rev. of Industr. Organizat., vol. 55, no. 1, spec. iss. SI, pp. 5-26, 2019.

[8] T.V. Velikanova, I.K. Kiforenko, A.A. Tolstonogov, "Analysis Of Modern Methodological Approaches To Pricing In The Field of Secondary Resources", Mediterranean J. of Soc. Sci., vol. 6, no. 6S7, pp. 289-294, 2015.

[9] K. Hervé Dakpo, Ya. Desjeux, Ph. Jeanneaux, L. Latruffe, "Productivity, technical efficiency and technological change in French agriculture during 2002-2015: a Färe-Primont index decomposition using group frontiers and meta-frontier", Appl. Econ., vol. 51, no. 11, pp. 1166-1182, 2019.

[10] N.Yu. Yaroshevich, "Modelling a competitive field of an enterprise: A structural approach", Upravlenets - The Managervol, 10, no. 2, pp. 31-40, 2019.

[11] L.A. Zaporozhtseva, T.V. Sabetova, I.Yu. Fedulova, "Assessment Of The Uncertainty Factors In Computer Modelling Of An Agricultural Company Operation", J. of Phys.: Conf. Ser. The proc. Int. Conf. Information Technologies in Business and Industry, 2019, art. no. 072029.

[12] W. Boshoff, R. van Jaarsveld, "Market Definition Using Consumer Characteristics and Cluster Analysis", South African J. of Econ., vol. 87, no. 3, pp. 302-325, 2019.
[13] G. Kuehne, R. Llewellyn, D.J. Pannell, "Predicting farmer uptake of new agricultural practices: A tool for research, extension and policy", Agricult. Syst., no. 156 (Sept), pp. 115-125, 2017.

[14] E.V. Zakshevskaya, M.V. Zagvozkin, T.V. Zakshevskaya, I.Yu. Fedulova, "Competitiveness improvement of agricultural companies based on the strategic management of their development", Econ. of agricult. and processing companies, no. 8, pp. 25-27, 2012.

[15] L. Zaporozhtseva, D. Kleimenov E. Kuznetsova, A. Orekhov, Yu. Tkacheva, "Transformation Of Socio-Economic Development Scenarios Of Russian Rural Areas In The Context Of Globalization". IOP Conf. Ser. Earth and Environmental Sci. The proc. of the conf. AgroCON-2019, art. no. 012029.

[16] F. de Melo, V.V. Maslennikov, E.V. Popova, T.L. Bezrukova, I.V. Kyksova, "Quantitative analysis in economics based on wavelet transform: a new approach”, Asian. Soc. Sci., vol. 20, no. 11, pp. 66-74, 2015.

[17] P. Ormerod, C.C.S. Caiado, "Market structure with interacting consumers", Rev. of behavioral econ., vol.1, no. 4. pp. 33-49, 2017.

[18] H. Esfahani, "Profitability of horizontal mergers in the presence of price stickiness", Europ. J. of Operat. Res., vol. 279, no. 3, pp. 941-950, 2019.

[19] V.F. Pechenevskiy, G.V. Zakshevskiy, "Procedure and forecast of the key parameters for allocation and development of crop production in the region", Modern econ.: probl. and solut., vol. 80, no. 8, pp. 92-103, 2016.

[20] A.I. Romanova, D.S. Romanov, O.V. Maksimchuk, A.V. Voronin, "Basic principles of innovation management in the urban economy of smart-city", Int. J. of Engineer. and Technol. (UAE), vol. 7, no. 4, pp. 412-415, 2018.

[21] L. Shulgina, I. Chernyshova, A. Shulgin, "An innovative system of the agro-industrial complex: sectoral and territorial aspects", IOP Conf. Ser. Earth and Environmental Sci. electr. Ed., Art. no. 012097, 2018. 